\begin{tabular}{|ll|}
\hline $\begin{array}{l}\text { Social Work/Maatskaplike Werk Vol } 57 \text { No 2; Issue } 4 \\
\text { http://socialwork.journals.ac.za/pub }\end{array}$ & doi:http://dx.doi.org/10.15270/52-2-928 \\
\hline
\end{tabular}

ECONOMIC STRESSORS AND COPING STRATEGIES OF SINGLE MOTHERS LIVING IN POVERTY IN ZIMBABWE Tanusha Raniga, Vimbainashe Matsai

The economic experiences of single mothers working in the informal economy receives little attention in public policy debates and social development transformative interventions. This study qualitatively explored the economic experiences of eight single mothers who worked in the informal economy in Zimbabwe. Drawing on African feminism, the authors present the biographical profiles of these mothers and discuss three key themes: financial hardships, social discrimination and safety nets. The article concludes with some considerations for harnessing the valuable contributions made by single mothers to the informal economy.

Keywords: economic experiences, economic stressors, coping strategies, informal economy, poverty, single mothers 



\section{ECONOMIC STRESSORS AND COPING STRATEGIES OF SINGLE MOTHERS LIVING IN POVERTY IN ZIMBABWE}

\section{Tanusha Raniga, Vimbainashe Matsai}

Ms Vimbainashe Matsai, Postgraduate student Department of Social Work \& Community Development, University of Johannesburg, Auckland, Johannesburg, South Africa.

Prof Tanusha Raniga, Department of Social Work \& Community Development, University of Johannesburg, Auckland, Johannesburg, South Africa.

Keywords: economic experiences, economic stressors, coping strategies, informal economy, poverty, single mothers

\section{INTRODUCTION}

There is a dearth of evidence in both the Global North and the Global South that addresses the effects of single motherhood on children and relatively few studies have specifically examined single mothers' experiences of economic stressors and coping strategies while working in the informal economy (Aloa, 2012; Amato, 2010; Azuka-Obieke, 2013; Dowd, 2017). This article presents one sub-set of data from a broader study that investigated the economic experiences and coping strategies of single mothers in Zimbabwe. It is not surprising that single mothers in Africa face social discrimination and economic exclusion in both the formal and informal economy as a result of gender inequality and sexual discrimination (Frye, 2007; Raniga, 2018).

Single-parent households continue to exist and have become a norm in contemporary society rather than an exceptional family structure. Globally, there has been an increase in the number of single-parent families and approximately three quarters of these families are single-mother households compared to single-father households (Goffman, 2013). Empirical evidence from the USA in 2018 revealed that the number of single-mother households was estimated at fifteen million (United States Census Bureau, 2018). Empirical evidence also reveals that the proportion of single-parent households has increased in Europe and Africa (Amaoteng, 2007; Holborn \& Eddy, 2011; Raniga \& Mthembu, 2016). In the UK the number of children living in single-mother households had increased from $13 \%$ in 1968 to $32 \%$ in 2016 (Nkerewu \& Udisi, 2016). In Africa the proportion of children who live in single-mother households ranges between $10 \%$ in Nigeria to $30 \%$ in Zimbabwe (Chani, 2018).

In contemporary South Africa, $44.6 \%$ of children reside in single-mother households that are predominantly dependent on state cash transfers (Statistics South Africa, 2016). An overview of international research on the economic experiences of single mothers reveals a multitude of distinct personal, social and political factors that played a prominent role in their survival strategies (Raniga, Boecker \& Mthembu, 2019).

Carbonari's (2013:.4) definition of a single mother was adopted for the purposes of this study and is described as a "non-cohabitating, never married, separated, divorced or widowed woman who lives with and supports at least one child 18 years and younger".

This is of particular interest to social workers as single-mother households have a much higher vulnerability to poverty, income insecurity and psychosocial stresses compared to two-parent households. For poor single mothers, poverty-related stress includes income insecurity, food insecurity, exposure to gender-based violence, work-life balance challenges, victimisation and illness (Raniga \& Mthembu, 2016). Research conducted in Zimbabwe by Mupfumira (2017) in Masvingo province revealed that one of the major challenges facing single mothers was income insecurity. Azuka-Obieke (2013) added that single-mothers were prone to low-economic status and that financial hardship was the primary factor that hindered the sustainable livelihoods in these households. Dowd (2017) points out that single mothers have reported higher levels of deprivation and experiences of life-threatening events 
compared to mothers in nuclear families. Malaba (2016) maintained that low educational levels, scarce jobs in the formal economy, ineffective state legislation and weak social protection policies for single mothers exacerbated their vulnerability to poverty in Zimbabwe.

Bearing the above deliberations in mind, this article presents empirical evidence from a larger study which adopted a qualitative methodology to gain greater insight into the correlates of poverty, gender relations and economic stressors from the perspectives of eight single mothers who resided in a lowincome community in Zimbabwe. Using African feminism as a foundational theory, this paper presents their biographical profiles and discusses three themes: financial hardships, social discrimination and safety nets. A central premise of this article is that the impact of socio-economic conditions, gendered power relations and structural poverty are factors that shape the work experiences and life choices of single mothers in Zimbabwe. The paper concludes with some considerations for practitioners to put in place transformative interventions and to advocate for institutional and government social protection policy changes as a way forward to harness the valuable contributions made by single mothers in the informal economy.

\section{THE PLIGHT OF SINGLE MOTHERS IN ZIMBABWE}

Single mothers in Zimbabwe are not given a fair platform from which they can engage the number of in productive work in the formal economy (Moyo \& Kawewe, 2012). The increase in the number of single mothers who survive on low-income jobs and their work as informal traders in the informal economy are key determinants of the feminisation of poverty (Kang'ethe, 2013). It is widely acknowledged that single mothers from Global South countries enter the informal economy out of necessity rather than choice. The jobs that women fill in the informal economy mirror those of the formal economy and this context reinforces women's inferior status in Zimbabwe (Goddard, 2015; Moyo \& Kawewe, 2012).

Nyakurerwa (2016) argues that the historical separation and access to gainful employment in the formal economy in Zimbabwe had a vital impact on single mothers' economic lives both within and outside the household. This scenario was aggravated by national increases in divorce rates, high mortality rates due to AIDS and high rates of teenage pregnancy. It is important to take note that single mothers' experiences are not just private issues but are profoundly connected to gender discrimination, social stigmatisation and structural concerns such as poverty and lack of access to funding and resources in the informal economy (Nyoni, 2012). Zimbabwe's commitment to the participation and empowerment of single mothers has been explicitly expressed through the constitution-making process. Section 17 of the Constitution was created on the foundational principles of human rights and ensures gender equality and protection of women from domestic violence, as well as prohibiting child marriages. It is also positive to note that women must constitute half of all members of established commissions both in private institutions and government departments.

The Poverty Assessment Survey of 2013 in Zimbabwe found that single-mother households had a poverty prevalence of $48 \%$ in 2015, while married-couple households' poverty prevalence stood at 39\% (Malaba, 2016). In addition, female-headed households constituted $34 \%$ of households and they contributed $29 \%$ of the national income, while male-headed households constituted $66 \%$ of households and contributed to $71 \%$ of the national income (Malaba, 2016). By 2016 the poverty prevalence for single-mother households had escalated to $68 \%$, while that of married couples had escalated to 50\% (Malaba, 2016). It is important to take note that from March 2019 the Total Consumption Poverty Line for one individual to purchase both food and non-food items in Zimbabwe was \$174.59. This implies that an average household with five individuals required $\$ 872.94$ to purchase food and non-food items as a determinant of the poverty datum line (Malaba, 2016). The food price hikes, cash shortages as well as the imposition of the $2 \%$ tax charge monetary policy and the devaluation of the bond note have affected single mothers' access to contract jobs and made trading in the informal economy unprofitable and unsustainable.

Evidently, Zimbabwe's structural economic and political instability has been a major contributing factor in the feminisation of the poverty of single mothers (Alao, 2012; Palaez \& Palaez, 2017). 


\section{AFRICAN FEMINISM}

In addressing gender relations in Africa, it is important to consider the specific historical and cultural contexts of nation states. The failure to consider how historical and socio-cultural contexts affects gender identities and the diversity of women's experiences may lead to misconceptions of the relevance of African feminism to social work practice. Socialist and radical feminism, which have a deep connect to African feminism, have over the past decade played a fundamental role in social work to raise consciousness, to ground an analysis of intersectional oppression and to empower women to take control of their lives (Aloa, 2012; Nnaemeka, 2006). Aloa (2012) argues that it is a "matter of letting African women define themselves as they wish" as the focus is on alleviating gender oppression and inequality.

This research took the single mothers' experiences of working in the informal economy as the starting point of its analysis and the central focus was on helping the women to understand the correlates of poverty, economic relations and gender inequality in their live choices. This meant that by rooting the single mothers' private troubles in their social positions as Black women who were residing in impoverished communities in Zimbabwe, the blame, stigma and guilt that they felt were removed (Nnaemeka, 2006). The researchers were mindful that the many levels of oppression experienced by these single mothers needed to be addressed simultaneously, as this is vital to African women's true emancipation.

\section{RESEARCH METHODOLOGY}

\section{The research context}

This study was conducted in Epworth, which is the fifth largest city in Zimbabwe and is considered a 'dirt-poor' squatter settlement which has minimal access to water, roads, sanitation services and electricity (Gandidzanwa, 2011). Epworth is located 12 kilometres outside of Harare and has high rates of unemployment, crime and prostitution, which have adverse effects on single-mother households (Gandidzanwa, 2011). The lack of food security, proper housing and secure accommodation bear testimony to the extreme poverty that is prevalent in the area (Nyakurerwa, 2016). Furthermore, single mothers play dual mother-father roles and are primary caregivers to meet the psychosocial and material needs of children (Kang'ethe, \& Munzara, 2014).

\section{The research}

A qualitative methodology was deemed appropriate to achieve the objectives of this research. Marlow (2011:44) stated that "Social work and Social Science research makes use of qualitative methods in order to enhance their understanding of people and the environment they live in, giving a clearer picture of what people go through and how they make meaning of their life". Exploring social phenomena as experienced by the participants forms another important function of qualitative research (Terre Blanche, Durrheim \& Painter, 2006). Particular to this study, the researchers applied an exploratory, descriptive design to describe the economic experiences and coping strategies of single mothers residing in Epworth.

According to Marlow (2011), research ethics refers to norms of conduct that distinguish between acceptable and unacceptable behaviour. The researchers were acutely aware of adhering to research ethics and protected the anonymity and dignity of the participants; they obtained written consent confirming their participation and for the audio-recording of the interviews (Marlow, 2011).

Ethical clearance was obtained in June 2019 from the Research Committee of the University of Johannesburg to conduct this study. This article reports on a qualitative phase of the larger study that aimed to explore the psychosocial, economic experiences and coping strategies of single mothers in the informal economy. The key objectives of this sub-study were:

- To explore the economic experiences of single mothers working in the informal economy in Zimbabwe;

- To explore the coping strategies adopted by single mothers in the face of their challenges; 
- To explore suggestions for transformative action.

\section{Selection of participants}

Selection of participants followed a purposive process where eight single mothers were selected using the snowball sampling strategy. The researchers obtained gatekeeper permission as part of the ethics approval to conduct the study. Hence a list of single mothers who resided in Epworth was obtained from the social worker at an NGO called Tariro House of Hope. Snowball sampling is described as 'chain referral' until an adequate number of participants is obtained (Terre Blanche et al., 2006). The advantage of this sampling method was that it facilitated the researchers' access to the existing social networks of the women in the community (Marlow, 2011). A total of five women were referred by the social worker at Tariro House of Hope and they were invited for an interview to clarify the purpose of the study and gain their consent to participate in the study. Subsequently each single mother referred one other single mother who resided in Epworth and was willing to participate in the study. Data saturation was reached with eight single mothers who met the following criteria:

- They were heads of their household;

- They had resided in Epworth for over 2 years;

- They were single and caring for minor children;

- They were willing to participate in the study.

The research process allowed the single mothers the opportunity to examine their individual economic experiences alongside the specificities of their life choices and social positions. Marlow (2011) explains that feminist research entails a deep reflexive process of connecting with the participants, empowering them and taking action collectively. The researchers and the women were perceived as equal partners in the study.

\section{Data-collection process}

One semi-structured interview was held individually with the eight single mothers. The semi-structured interview gave the researchers an opportunity to clarify the purpose and objectives of the study and to explore whether the women were willing to share their life stories (Marlow, 2011). Secondly, it provided the forum to engage the women in understanding their biographical profiles and experiences within the broader socio-economic and gendered framework. Each life story collected during the interview provided insight into how an impoverished community with high levels of unemployment, crime and poverty had a profound impact on the lives of the single mothers living under these economic conditions and working in the informal economy. The topics covered in the interview included: livelihood strategies, challenges faced and coping strategies for survival. The use of open-ended questions allowed for probing and to get clarity about the single mothers' economic experiences and coping strategies.

The duration of each interview session was one hour. Since this study presents the results from a small sample of eight women, the findings cannot be generalised. However, prolonged engagement and the rich descriptive details shared by the participants about their economic experiences served to enhance the trustworthiness of the findings (Terre Blanche et al., 2006). The researcher enhanced the credibility of the study through member checking: this allowed participants the opportunity to clarify what their intentions were, corrected any possible errors, and provided additional information when necessary.

The main challenge that the researchers experienced was language. The interviews were conducted in Shona by one of the researchers and it must be acknowledged that in the translation from Shona to English some meaning may have been lost. The researchers did, however, engage a peer reviewer who was fluent in Shona to cross-check the transcripts and this enhanced the trustworthiness of the data.

The data were thematically and critically analysed with reference to the literature (Terre Blanche et al., 2006) and the precepts of African feminism. Clarke and Braun's (2013) five-step framework was used to guide the analysis. The first step comprised preliminary exploration of the data: the researchers 
transcribed the interviews based on the audio-recordings. The second step entailed coding of the data. The researchers referred to the transcribed interviews, then segmented and labelled the texts. The third step involved the use of similar codes to develop preliminary themes. Step four included connecting the interrelating themes and aligning them with those that were either common or different. Step five focused on synthesising the findings into the three key themes which form the central premise of this article and the discussion below.

\section{DISCUSSION OF RESULTS}

The findings presented were distilled from the analysis of one face-to face semi-structured interview conducted individually with eight single mothers as well as from meetings and observations shared between the researchers on the analysed data. The discussion of the findings will be presented in two sections:

- A biographical profile of the participants

- A discussion of three themes, namely financial hardships, social discrimination and safety nets.

\section{Biographical profile of research participants}

A profile of the research participants is presented in the table below:

\section{TABLE 1}

THE BIOGRAPHICAL PROFILE OF THE RESEARCH PARTICIPANTS

\begin{tabular}{|l|l|l|l|l|c|}
\hline $\begin{array}{l}\text { Participant } \\
\text { name } \\
\text { (Pseudonym) }\end{array}$ & Age & $\begin{array}{l}\text { Reasons for being } \\
\text { a single mother }\end{array}$ & Employment status & Level of education & $\begin{array}{l}\text { Number of school- } \\
\text { going } \\
\text { children } \\
\text { being taken care of }\end{array}$ \\
\hline Naomi & 56 & Widow & Domestic worker & Never attended school & 2 \\
\hline Prisca & 55 & Divorced & Informal trader & Grade 11 & 2 \\
\hline Rumbidzai & 24 & Separation & Domestic worker & Grade 11 & 1 \\
\hline Hilda & 42 & Widow & Cook for an NGO & Grade 8 & 2 \\
\hline Sandra & 44 & Widow & Cross-border trader & Grade 11 & 1 \\
\hline Susan & 45 & Separation & Informal trader & Grade 7 & 2 \\
\hline Tabeth & 31 & Widow & Informal Trader & Grade 11 & 2 \\
\hline Tryness & 31 & Widow & Informal Trader & Grade 10 & 1 \\
\hline
\end{tabular}

Table 1 reveals that one of the mothers was 24 years old; two were 31; three were between 40 and 45 , and two were over $50(\mathrm{~N}=8)$. The mean age was 41 years. This finding correspond with the findings of Clarke and Hamplová (2013) qualitative inter-country study conducted in Ethiopia, Malawi, Kenya and Zimbabwe which revealed that there is a $60 \%$ probability rate of becoming a single mother by the age of 45 in urban populations.

Table 1 illustrates that all the women had low levels of education and did not complete school. Sandra was the only one who had completed any form of post-secondary training. She completed two courses of training as a nurse aid and she obtained a flower arrangement certificate. It is not surprising in Zimbabwe that women have low literacy levels as gender discrimination and male hegemony are deeply embedded in the society. According to Härkönen (2018), these low literacy levels imply that single mothers have little or no access to secure jobs in the formal economy and are vulnerable to income insecurity and poverty. Some of the comments made by the women were as follows:

I have never attended school. I grew up with no parents, which resulted in me resorting to working providing manual labour at the farms in Shamva. (Naomi)

I don't remember which year I stopped going to school, but I did my O level (Grade 11), I did not pass well and my parents did not acknowledge the importance of education for the female child, so that was that. Only had ZJC certificate as I couldn't supplement my education. (Prisca)

I can't remember what year I stopped attending school but it was in Form 1 (Grade 8), because when I was about to start my Form 2 first term I was stopped from continuing. (Hilda) 
I was last in school in 2009, that's when I did my O level (Grade 11). My guardians were paid after farming season, which occurred once a year. That's how they managed to pay for my fees and all expenses but in 2009 registration fees were raised. (Rumbidzai)

In terms of school I finished in Grade 7. (Susan)

I went to school until I was in Form 3 (Grade 10), that is when my parents stopped paying fees; they could not afford anymore. (Tryness)

The empirical evidence of the low literacy levels of the women was clearly a factor in their marginalised status as single mothers seeking job opportunities in the formal work sector (Chani, 2018) and thus they worked in the informal economy out of necessity rather than by choice. Consistent with studies conducted by Raniga and Ngcobo (2014), low literacy and numeracy skills are widely acknowledged as key determinants of income insecurity and poverty.

Table 1 also reveals that the adult to child ratio was 1.6. According to Amato (2010), single-mother households comprise $40 \%$ of the total $70 \%$ of who live in poverty-stricken areas in Zimbabwe. Two of the women reported that they were working on contract as domestic workers and one was employed as a cook at a non-governmental organisation. Five of the women were operating their own small businesses in the informal economy. Mwaniki (2011) stated that the occupations that women fill in the informal economy often reinforces their inferior status. Raniga (2018) argues further that women in this sector are at the lowest end of the social stratum and many are subject to gender-based violence and discrimination, which impacts on the sustainability of the household.

The theme on financial hardships is discussed below.

\section{Financial hardships}

According to Stiglitz, Sen and Fitoussi (2010), economic wellbeing is a multidimensional concept encompassing income, wealth and consumption. Table 1 revealed that none of the women received a steady monthly income. Five of the single mothers were informal traders, mainly selling fruits and vegetables. These findings correspond with the findings of Mwaniki (2011), who revealed that 94\% of Zimbabweans are unemployed and the majority work part-time in the informal economy. In addition, Mangena and Ndlovu's (2013) findings from a quantitative sample of 54 market-stall vendors operating in Harare found that 22 of the respondents, who were single mothers, earned between 54 and 100 Zimbabwean Dollars (R80 - R150) on a weekly basis. Some of the comments made by the women are as follows:

I do zvemusika (small informal market). I have no other means of the money that I'm making, it's the musika that helps me to survive. I sell tomatoes and vegetables. At the moment, things are now tough as prices are high, but initially, I used to sell drinks and snacks/chips, but now it's now difficult to buy and resell. Approximately, a week I get about \$50/60. (Susan)

I sell tomatoes, vegetables, and just that things are now tough, prices are higher, and people are choosing to eat vegetable-less or tomato-less foods. Roughly, I get \$10 (R15) a day. (Tryness)

From the sentiments expressed above by the women who were informal traders, it is clear that their private experiences were deeply connected to the structural economic crisis in Zimbabwe, which was beyond their control. The income insecurity they felt was due to the fluctuating currency exchange rates, which made their monthly household income very difficult to sustain. The mothers spoke about prices for basic commodities such as public transport, cooking oil, soap, electricity and water bills, which increased on a daily basis. Inflation rates were high and they commented that the government was not doing anything to change or stabilise the economy.

However, it is interesting to take note that these women did share some positive sentiments in the interview about 'Eco Cash', which was an innovative mobile payment system used in Zimbabwe and 
which enabled their customers to pay for their goods directly from their mobile phones (Eco cash, 2018). Eco cash has been recognised as a valuable system that has substituted the cash flow crisis in Zimbabwe. However, these women also spoke about the challenges they faced with the high service costs they had to pay monthly for 'Eco cash', which left them with a menial amount for meeting their expenses. A further challenge they raised was that the use of Eco cash made them vulnerable to high levels of fraud and crime.

Sandra spoke about her cross-border trading business as the main source of income for her family. She stated that she bought clothes from South Africa and sold them in Zimbabwe. Kanyenze (2010) reveals that cross-border trading has become another means of economic survival for many poor women, who go to neighbouring countries such as South Africa, Botswana and Mozambique to sell their own items and then purchase clothes, beauty products and homeware items for resale in Zimbabwe.

I get money when I sell clothes or random goods that are available at the time. Sometimes, I sell bales from Mozambique of the clothes that are in demand or in season, for example, jackets in winter, sometimes I go and buy alone, sometimes I send someone. (Sandra)

Another important point made by all the women about their financial hardship was that their respective livelihood strategies did not adequately cover their monthly household expenses. Some of the comments made are as follows:

Haaaa, I cannot lie to you, the money I am getting is not enough, my sister. At the present moment, I do not have all the basic commodities, sugar and cooking oil. (Hilda)

It is difficult to make ends meet, it is a constant stress, my income and expenses are not at par because the cost of living is increasing every day. (Prisca)

Many of the women perceived their private experiences were deeply connected to social discrimination, the addressed in the following section.

\section{Social discrimation}

A central focus of the interview was on raising the women's consciousness about the complex interplay of power imbalances working in the informal economy. All the single mothers stated that they were perceived as inferior and subjected to social discrimination by many in society. This confirms the findings presented by Nyoni (2012) that single mothers in Zimbabwe are subjected to stigma and discrimination by virtue of their single motherhood status. Rumbidzai shares her experience as follows:

Married woman judge you differently and they are very discriminatory. There is a lack of empathy, and respect even in the family. You are looked down upon, men think you are easy; they want transactional relationships, Family think you are a burden. Community think you know nothing about marriage and living with people who are married.

According to Siti (2011), the stigma and negative perceptions that society holds about single-mothers hinder them from playing an active and valuable role in society. Tryness comments:

We are looked down upon, we are viewed as sex workers and promiscuous. Stigma within the community is bad, the level that they look at us with. We are judged differently by the same society that we serve.

Hilda spoke about the perception that single mothers are perceived as people who have no morals and who are always after married men.

The community seems to be less respectful towards single mothers who stay alone, and always want to know how you are surviving as they least expect us to make it in life. It's an issue of stigmatisation, such as one saying they wonder if I can afford or how I can afford to buy bread, the community expects less from us. (Hilda)

This finding corresponds with Maldonado and Nieuwenhuis (2018), who revealed that single mothers and their children face discrimination, higher levels of poverty, and stigma. Children who grew up in 
single-mother households are disadvantaged in many ways and this affects their psychological wellbeing in adulthood (Maldonado \& Niewenhuis, 2018).

The single mothers also stated that this discrimination disadvantaged them and restricted access to funding in the informal economy. Evidently the low levels of education as illustrated in Table 1, the precarious political environment, poor access to jobs in the formal work sector combined with inadequate legislation and weak social protection policies in Zimbabwe were key structural factors that profoundly hampered the income security and sustainable livelihoods of all the single-mother households in this study.

The theme of safety nets is elaborated on in the following section.

\section{Safety nets}

In Africa families have always served as a prime safety net for the protection and sustainability of its members. Aloa (2012) contends that there are three support mechanisms, namely private household systems (family ties), organisation-based systems (faith based organisations, women's clubs) and the state, which helps women to cope with their economic stresses. In this study the women revealed a combination of family ties as well as organisations that helped them cope with their financial hardship. Some of the comments shared by some of the women about family are:

I can say support is from my children. My girl finished her Form 4 in 2015 but up to now I haven't managed to take the results as we do not have the money. So, sometimes she can go and do some freelance manual work and get paid and then she brings something at home. (Hilda)

I am surviving through the help of my son (19 years) who does part-time/freelance jobs in MASASA, such as offloading cement at warehouse. (Naomi)

My elder son-in-law, he does help most times, however, he had a family problem when his father had cancer for six months, so he was under pressure financially; however, miraculously he still helps me when I am in a crisis. (Prisca)

I sometimes receive money from my other sisters and brothers, that's what we use for other expenses at times. (Rumbidzai)

In terms of support, my brother supports me from time to time; however, he recently married, his expenses now have to cater for his new family, otherwise he does support me when he can as he goes to work. (Sandra)

One needs to bear in mind that these informal support systems are unsustainable and ad hoc in nature, as economic support received through kinship ties are inconsistent and irregular. This makes such safety nets inadequate as a means to supplement household income and a much more comprehensive social security system is required to meet the needs of single mothers working in the informal economy.

Many of the women in this study were of the view that the state needed to provide monthly cash transfers to them to help them meet their child care needs. This is a major legislative gap in Zimbabwe as the government does not provide social grants or cash transfers to single mothers. According to Raniga and Ngcobo (2014), the provision of social grants provides an important social protection and economic safety net for single mothers in South Africa. Some of the views the women shared were:

\section{I am not receiving any kind of support from the community or government. (Naomi)}

The community does not provide me with any support. (Prisca)

Here in Epworth there is no support, I have never heard of community assistance for single mothers. (Rumbidzai)

Some of the single mothers resorted to faith-based organisations as a means to obtain psychosocial support. According to Regnerus (2013), access to religious institutions is a valuable form of support that single mothers turn to during times of financial hardship. Furthermore, faith-based organisations are 
helpful in strengthening family relationships when the children are bitter towards their parents as a result of economic stressors. Some of the comments made by the women are:

I go for counselling at church and share my problems with my pastor at church. She is a female pastor and that's very fortunate for me. (Hilda)

I go to church, the Morning Prayer band where you are free to express challenges you face as a single mother, for example, not being able to sleep well etc. I only try to leave everything to God. (Naomi)

I can rely on my pastors; I have two female pastors who have been in my situation before. They understand, they are a very good counsel. Every time I go and talk to them, I always come back relieved. (Rumbidzai)

All the women in this study stated that they actively participated in women's groups which were run by the church and this helped them to cope. Regerus (2013) stated that a deep connection with the Creator as well as psychosocial support from family and friends provide hope for single mothers during times of financial stress.

\section{CONCLUSIONS AND RECOMMENDATIONS}

The voices of eight single mothers in this qualitative study conducted in an impoverished community called Epworth in Zimbabwe have shown that their economic experiences are not just private troubles but are profoundly connected to structural concerns such as lack of state intervention, social protection legislation and economic exclusion. The findings of this study also corroborate other South African research by Thabethe and Mathe (2011), and Raniga and Ngcobo (2014), who revealed that single mothers' ability to earn an income in the informal economy is often fragmentary and irregular. Of serious concern is the finding that none of the single mothers had access to social protection from the state amidst the political and economic crisis in Zimbabwe.

Based on these conclusions, the following recommendations are made:

- Transformative interventions should include the establishment of a business forum to assist single mothers to network and improve their educational qualifications;

- It is important that policy makers advocate for social protection legislation in Zimbabwe to assist single-mother households to supplement the menial income received from working in the informal economy;

- National policy and regulatory changes which expand access to funding for women who work as informal traders is necessary;

- Regulatory child care subsidies are necessary in order to assist single mothers to gain more control over their social, political and economic lives;

- The lobbying by social workers and other advocacy groups to ensure visibility and accountability by the state to adequately address the economic and educational needs of single mothers who work in the informal economy is necessary;

- This study represented a limited sample of eight single mothers from one impoverished community in Zimbabwe and does not represent other SADC countries in Africa. This clearly warrants further qualitative research to be conducted to explore the economic experiences of single mothers across different countries in Africa.

\section{REFERENCES}

AMATO, P. R. 2010. The impact of family formation changes on the cognitive, social, and emotional well-being of the next generation. Journal of Marriage and Family, 72(3): 650-666.

AMAOTENG, A.Y. 2007. Towards a conceptual framework for families and households. In: AMAOTENG, Y. \& HEATON, T.B (eds.). Families and households in post-apartheid South Africa: Socio-demographic perspectives. Cape Town: Human Sciences Research Council. 
ALAO, A. 2012. Mugabe and the politics of security in Zimbabwe. Canada: McGill-Queen University Press.

AZUKA-OBIEKE, U. 2013. Single parenting, psychological well-being and academic performance of adolescents. Nigeria: University of Lagos.

CHANI, C. 2018. Informal cross-border trade: A review of its impact on household poverty reduction in Zimbabwe. East London: University of Fort Hare. (M thesis)

CLARKE, S. \& HAMPlovÁ, D. 2013. Single motherhood in Sub-Saharan Africa, A life perspective. Montreal: Canada.

CLARKE, V. \& BRAUN, V. 2013. Teaching thematic analysis: Overcoming challenges and developing strategies for effective learning. The Psychologist, 26 (2): 120-123.

CARBONARI, N. K. 2013. Perceived quality of life for single mothers living in affordable housing in Columbus. Ohio State University: Ohio.

DOWD, N. E. 2017. In defence of single families. New York: New York University Press.

ECO CASH. 2018. "Eco Cash Zimbabwe: About Us". Harare: Eco Cash Zimbabwe.

FRYE, I. 2007. The 'Second Economy' As intellectual sleight of hand. Africanus: Journal of Development Studies, 37 (2):175-190.

GANDIDZANWA, P. 2011. Attitudes and practices towards water supply and sanitation facilities: The case study of Epworth Upgrading Programme. Zimbabwe: University of Zimbabwe. (M thesis) GOFFMAN, I. 2013. Single mothers and their children: A new American dilemma. Washington, Dc: Urban Institute Press.

HÄRKÖNEN, J. 2018. Single-mother poverty: How much do educational differences in single motherhood matter? In: NIEUWENHUIS, R. \& MALDONADO, L.C. (eds.). The triple bind of singleparent families: Resources, employment and policies to improve well-being. Great Britain: Policy Press.

HOLBORN, L. \& EDDY, G. 2011. First steps to healing the South African family. Johannesburg: South African Institute of Race Relations.

KANG'ETHE, S. M., \& MUNZARA, M. 2014. Exploring an inextricable relationship between feminization of poverty and feminization of HIV and AIDS in Zimbabwe. Journal of Human Ecology, 47 (1): 17-26.

KANYENZE, G. 2010. Giving voice to the unprotected workers in the informal economy in Africa: The case of Zimbabwe. No. 22. International Labour Organisation.

MOYO, O., \& KAWEWE, S. 2012. The dynamics of a radicalized, gendered, ethicized and economically stratified society: Understanding the socio-economic status of women in Zimbabwe. Feminist Economics, 8:163-181.

MALABA, J. 2016. Poverty measurement and gender: Zimbabwe's experience. Inter- agency and expert group meeting on the development of gender statistics. United Nations: New York.

MARLOW, C. 2011. Research methods for generalist social work $5^{\text {th }}$ ed. Brooks/Cole: Cengage Learning.

NIEUWENHUIS, R. \& MALDONADO, L.C. (eds.). 2018. The triple bind of single-parent families: Resources, employment and policies to improve well-being. Great Britain: Policy Press.

MANGENA, T. \& NDLOVU, S. 2013. Implications and complications of bride price payment among the Shona and Ndebele of Zimbabwe. International Journal of Asian Social Science, 3: 472-481.

MUPFUMIRA, I. M. 2017. Lived experiences of single parent families in A high density suburb in Masvingo Province, Zimbabwe. Advances in Social Sciences Research Journal, 423: 107-121. 
MWANIKI, J. 2011. The impact of informal cross border trade on regional integration in SADC and implications for wealth. Harare: Great Zimbabwe University.

NNAEMEKA, O. 2006. Women, creativity, and dissidence. Introduction: Side-line insurgencies and gendered art. Meridians, 6(2):1-21.

NYAKURERWA, T. S. 2016. An analysis of the law and the effectiveness of government and nongovernmental organizations' interventions in curbing under age commercial sex work in Epworth and along the Mukuvisi River Bank, Harare, Zimbabwe Harare: University of Zimbabwe. (M thesis) NKEREWU. J., \& UDISI, V. 2016. Single-parent families and their impact on children: A study of Amassoma Community in Bayelsa State, European Journal of Research in Social Science, 20-60.

NYONI, K. 2012. Zimbabwe: Is divorce an indication of women's empowerment? [Online] Available: http://Www.Genderlinks.Org.Za/Article/Zimbabwe-Is-Divorcean-Indication-of-WomensEmpowerment-2012-02-15 [Accessed 02/06/2020].

PALAEZ, C. M. \& PALAEZ C. A. 2017. Global recession Risk: Dollar devaluation and the world economy. New York: Thorne Publishers.

RANIGA, T., BOECKER, M. \& MTHEMBU, M. 2019. Economic experiences and sustainable livelihoods of single mothers employed in the formal work sector In Germany and South Africa. Social Work/Maatskaplike Werk, 55 (4): 379-392.

RANIGA T. 2018. Poverty alleviation, social protection policy and sustainability of economic development co-operatives: Voices of women residing in Bhambayi, Kwa Zulu-Natal, South Africa. Social Work/Maatskaplike Werk, 54(4): 395- 406.

RANIGA, T. \& MTHEMBU, M. 2016. Family resilience in low income communities: A case study of an informal settlement in KwaZulu-Natal, South Africa. International Journal of Social Welfare, August 2016. doi: 10.1111/ijsw.12243

RANIGA, T. \& NGCOBO, N. 2014. Economic experiences of single mothers in Bhambayi, KwazuluNatal, South Africa. Social Work/ Maatskaplike Werk, 50 (4): 516-528.

REGNERUS, M. D. 2013. Linked lives, faith, and behaviour: Intergenerational religious influence on adolescent delinquency. Journal for the Scientific Study of Religion ,42:189-203.

SITI, Z. 2011. Attitude towards the mentally ill patients among a community in Tampoi, Johor, Malaysia. Malaysia Journal of Public Health, 20: 3-5.

STIGLITZ, J. E., SEN, A., \& FITOUSSI, J.P. 2010. Report by the Commission on the Measurement of Economic Performance and Social Progress. [Online] Available: http://graphics8.nytimes.com/packages/pdf/business/Stiglitzreport.pdf [Accessed 22/8/2020].

TERRE BLANCHE, M., DURRHEIM, K. \& PAINTER, D. 2006. Research in practice: Applied methods for social sciences. Cape Town: University of Cape Town Press.

THABETHE, N., \& MATHE, S. 2010. Anti-poverty strategy in rural KwaZulu-Natal: Contradictions and opportunities for women in poultry farming. Agenda, 84:91-100.

UNITED STATES CENSUS BUREAU. 2018.1 Fact sheet: United States: Alabama. American Community Survey 5-Year Estimates. [Online] Available: http://factfinder.census.gov/ [Accessed 11/7/2020]. 